\title{
Science as a never-ending quest
}

J. R. Ravetz

The Nature of Science: The History of Science in Western Culture Since 1600. By David Knight. Pp. 215. (André Deutsch: London, 1977.) £4.95.

IN companison with many other disciplines studying human behaviour, the history of science is quite peaceful and self-confident. Although divergences of approach have always existed, they have never polarised the whole field. The present book represents a considerable shift in the consensus of what the history of science is all about, and yet it is done in a relaxed, matter-of-fact way, totally devoid of programmatic pronouncements.

What David Knight argues, in The Nature of Science, is that it lies as much in the activity of research and its context, as in the results we accept as valid. The supposed 'hard core' of objective facts, which could be studied on their own by philosophers and historians, is now blended into the matrix - social and intellectual-of scientific work.

In order to exhibit this view of science, David Knight must approach history in an unorthodox way. Instead of treating 'periods' in chronological sequence, he uses 'themes'. We have a progression, from the more philosophical ("Science as a Complex Activity", and ". . . as Explanation"), to the more social, linking science to its community, and discussing careers, Government and utility. The bridgesection is on "Science and Not Science".

It is very refreshing for a person familiar with the history of science to see the materials sorted in this way. But this arrangement has its costs, most notably in the loss of a chronological sense for the whole story.

The general literary style is relaxed and conversational. The book makes enjoyable reading, but the shape of events in history becomes quite blurred as the narrative slides from one topic to another.

The history that is told in such a way, especially in a small book cover. ing such a wide range, inevitably becomes a personal statement. The materials reflect the author's own interests; here, social and institutional aspects of English science absorb much space. Also, the text is liberally sprinkled with the author's own generalisations and morals. They are

recognisable as such, and fit with Dr Knight's commitment to the view that history, like natural science, is a neverending quest, best not left exclusively with professionals.

Everyone will find fault or favour with his/her own selection of wisdom. I am intrigued by the suggestion that eighteenth-century chemistry was hindered by the Newtonian orthodoxy; this is a far cry from the classic ridicule of 'phlogiston' as the nonsense theory that awaited overthrow by Lavoisier. Some throwaway statements have

\section{Genetic expression in plants}

Molecular Aspects of Gene Expression in Plants. Edited by J. A. Bryant, Pp. 338. (Academic: London, New York and San Francisco, 1977.) £9.60; $\$ 21$.

THIs seven-chapter volume has been compiled by four authors, one of whom is the editor. Together they have many years experience with plant nucleic acids, and they have pooled their joint approaches and expertise to produce an overall view in what the dust cover calls "the first book to deal specifically with gene expression in plants".

The first half is a mine of basic information on the properties and functions of DNA, RNA and proteins in cells, and freely uses information from non-plant sources. The first chapter on nuclear DNA deals effectively with the extraction and properties of DNA, the structure of chromosomes and the modifications and variations that can occur in the genome following synthesis and turnover of DNA in vivo. Bryant has done a service in confining the term "nucleohistone" for the DNA-histone complex and "chromatin" for the DNA-histone-acidic protein complex throughout the volume. Although the classification given for histones is the " $f$ " nomenclature, it would have been helpful to undergraduate readers if the " $H$ " nomenclature, which they will surely encounter in the literature, had been included. Nucleosomes receive brief mention only, and although buoyant density fractionations of DNA are discussed, the use of sucrose density fractionations is not. rather strong implications; to say that conservatives were "naturally enough often right in resisting innovations", opens up new and challenging perspectives on the history of scientific revolutions and indeed on the methodology of science.

So here is a book to be enjoyed rather than dissected; a very useful introduction to a growing new historiography of science.

$J$. R. Ravetz is Reader in the History and Philosophy of Science at the University of Leeds, UK.
The chapter on RNA structure and metabolism provides a lucid account of the different classes of RNA, outlining their separation and function as intermediates for the translation of genetic information in protein synthesis. Considerable space is given to the topic of precursor RNA molecules and their processing to ribosomal RNA in both prokaryotic and eukaryotic plants. The possible role of tRNA molecules and the stability and function of mRNA are discussed in relation to well studied examples of the control of transcriptional and translational events in plants.

There follows a straightforward account of the translation steps in protein synthesis with frequent comparisons with bacterial and mammalian systems. Most of the plant information has been gleaned from the extensive work on germinating seeds and proteinsynthesising cell-free systems from wheat-germ. Attention has properly been drawn to the gaps in our knowledge for plants. The diagrams and schemes are somewhat repetitious, but the points are very clearly made.

A useful chapter is devoted to gene expression in chloroplasts and mitochondria, to include the basis of their role in cytoplasmic inheritance and the degree of their developmental autonomy. The nature and replication of chloroplast DNA, the transcription of RNA and the assembly of chloroplast proteins (particularly fraction I protein), are presented in an interesting way. The section dealing with mitoohondria is brief, but sets out present knowledge of their DNA structure and RNA transcription products, together 